\title{
Kesultanan Jambi dalam Jaringan Perdagangan Antar Bangsa (1480-1834)
}

\author{
Arif Rahim \\ Program Studi Sejarah, FKIP Universitas Batanghari \\ Jl. Slamet Ryadi, Broni-Jambi \\ Correspondence email:
}

\begin{abstract}
Abstrak. Tulisan ini membahas tentang kerajaan Jambi dan keberadaannya sebagai sebagai negara yang terletak di jalur perdagangan internasional. Hal ini menarik diteliti karena masa keberadaannya bersamaan dengan masa keemasan perdagangan antar bangsa yang melibatkan negera-negara emporium yang terletak di sepanjang jalur perdagangan mulai dari Cina di sebelah timur hingga ke Laut Tengah di ujung Barat. Masa ini oleh sejarawan dikatakan masa kemakmuran negara emporium Asia. Dengan menggunakan pendekatan multi dimensional dan didukung oleh penerapan metode sejarah yang mengacu pada prosedur penelitian sejarah ilmiah, hasil penelitian ini diharapkan dapat memberi penjelasan terhadap masalah pokok yang diajukan dan seterusnya berkontribusi terhadap pengembangan ilmu pengetahuan terutama tentang sejarah lokal Jambi. Selain itu dapat dijadikan sebagai bahan pertimbangan oleh institusi terkait dalam rangka melestarikan nilai-nilai sejarah dan budaya dan untuk pengembangan dan pembangunan daerah. Hasil penelitian menunjukan bahwa daerah Jambi telah terlibat dalam jaringan perdagangan antar bangsa sejak permulaan abad Masehi, namun sifatnya mengalami pasang surut. Dari abad ke 3 hingga abad ke 7 keterlibatan Jambi tampak pada eksistensi kerajaan Koying, Tupo, Kantoli dan Melayu. Dari abad ke 7 - hingga abad ke 11 peran itu merosot karena kerajaan Melayu berada dikuasai oleh Sriwijaya yang berpusat di Palembang. Ketika Sriwijaya melemah pada abad ke 11, Melayu melepaskan diri dan kembali tampil sebagai bandar perdagangan yang penting di Nusantara. Memasuki abad ke 12 peran itu kembali merosot karena adanya adanya saingan dari bandar perdagangan lain yang terletak di pesisir timur Sumatera Utara, serta adanya perdagangan langsung ke pedalaman. Kerajaan Jambi kembali berdiri pada akhir abad 15, mencapai puncak kejayaannya pada abad ke 17 ketika merica menjadi komoditas penting dalam perdagangan internasional. Sebagai negeri penghasil merica yang besar, Jambi muncul sebagai bandar perdagangan penting yang ramai dikunjungi pedagang asing maupun pedagang Nusantara. Tetapi sejak akhir abad 17, Jambi mengalami kemunduran. Penyebabnya adalah kekakalahan Jambi atas Johor dalam peperangan yang terjadi berulangkali dalam rentang tahun 1667 hingga 1673. Sebab-sebab lainnya adalah konflik internal kerajaan, dan intervensi Belanda dalam uurusan pemerintahan kerajaan, serta anjloknya harga merica di pasaran internasional. Merosotnya harga merica menyebabkan menurunnya penghasilan kerajaan dan masyarakat, sehingga menyebabkan keengganan para pedagang untuk dating ke Pelabuhan Jambi. Pada abad 19 pelabuhan Jambi tidak lagi dikunjungi oleh pedagang - pedagang maritim Nusantara
\end{abstract}

Kata Kunci: Perdagangan, Kesultanan Jamb

Abstract. This paper discusses the Jambi kingdom and its existence as a country located on the international trade route. This is interesting to study because the period of its existence coincided with the golden age of trade between nations which involved emporium countries that were located along the trade route from China in the east to the Mediterranean in the western tip. This period is said by historians to be the prosperous era of the Asian emporium. By using a multi-dimensional approach and supported by the application of historical methods that refer to scientific historical research procedures, the results of this study are expected to provide an explanation of the main problems posed and thus contribute to the development of science, especially about Jambi's local history. In addition, it can be used as material for consideration by related institutions in order to preserve historical and cultural values and for regional development. The results of the study show that the Jambi region has been involved in international trade networks since the beginning of the century $A D$, but its nature has experienced ups and downs. From the $3 r d$ century to the 7th century Jambi's involvement was evident in the existence of the Koying, Tupo, Kantoli and Malay kingdoms. From the 7th century to the 11th century that role declined because the Malay kingdom was controlled by Srivijaya, which was centered in Palembang. When Srivijaya weakened in the 11th century, Malays broke away and re-emerged as an important trading port in the archipelago. Entering the 12th century, this role has declined again due to competition from other trading ports located on the east coast of North Sumatra, as well as direct trade to the interior. The Jambi kingdom was re-established at the end of the 15th century, reaching its peak in the 17th century when pepper became an important commodity in international trade. As a large pepper producing country, Jambi emerged as an important trading port which was visited by both foreign and Nusantara traders. But since the end of the 17th century, Jambi has been in decline. The cause was Jambi's defeat of Johor in repeated wars between 1667 and 1673. Other reasons were the internal conflict of the kingdom, and the Dutch intervention in the affairs of the royal government, as well as the falling price of pepper on the international market. The decline in the price of pepper led to a decrease in the income of the kingdom and the community, thus causing the reluctance of traders to come to Jambi Port. In the 19th century the port of Jambi was no longer visited by maritime merchants of the archipelago.

Keywords: Trading and Jambi Sultanate 


\section{PENDAHULUAN}

Dilihat dari aspek temporal kajian sejarah, daerah Jambi termasuk pada daerah yang memiliki ruang pembahasan sejarah terpanjang jika dibandingkan dengan kebanyakan daerah lainnya di Indonesia. Informasi sejarah tentang Jambi telah terkuak sementara di periode yang sama daerah-daerah lain masih tertutup kabut sejarah yang sangat tebal. Rentang Sejarah Jambi beriringan dengan berkembangnya jalur pelayaran niaga antar bangsa pada awal abad Masehi. Jalur itu membentang mulai dari Cina di sebelah timur ingga ke Iskandariah di pantai Laut Tengah, melalui Laut Cina Selatan, Selat Malaka, Lautan Hindia, terus ke Teluk Persia, atau ke Laut Merah. Para ahli sejarah meyakini bahwa keberadaan jalur tersebut telah mendorong munculnya kerajaan-kerajaan dan pelabuhan dagang di sepanjang rute tersebut. Data-data sejarah yang bersumber dari catatan-catatan Cina telah mengungkakan bahwa di daerah Jambi telah muncul beberapa kerajaan mulai abad ke 3.Lebih jauh diketahui bahwa dalam rentang abad 3 sampai abad 7 di kawasan Sumatera bagian tengah dan selatan terdapat tiga kerajaan yaitu Koying, Tupo dan Kantoli, dan ketiganya terlibat aktif dalam pergangan antar bangsa.

Eksistensi Koying diketahui berdasarkan catatan yang dibuat oleh Kuang-Tai dan Wan-Chen (222-280) serta ensiklopedi Tung-Tien ditulis oleh Tuyu (375). Sumber-sumber tersebut menerangkan bahwa di kerajaan Ko-ying ada gunung api dan di selatannya ada sebuah teluk bernama Wen. Dalam teluk itu ada pulau bernama Pu-Lei. Penduduk yang mendiami pulau itu semuanya telanjang bulat, laki-laki maupun perempuan, kulit berwarna hitam kelam, giginya putih-putih dan matanya merah. Mereka melakukan perdagangan secara barter dengan para penumpang kapal yang berlabuh di Koying. Dagangan mereka adalah ayam, babi serta buahbuahan yang mereka pertukarkan dengan berbagai benda logam. Memperhatikan ciri-ciri fisik tersebut dapatlah diartikan bahwa mereka bukan termasuk rumpun Melayu tetapi mungkin lebih mirip rumpun Proto-Negrito yang sebelumnya telah menghuni daratan Sumatera (Sartono, 1992).

Dari sumber India dan Funan diketahui bahwa pada abad ke 3 kerajaan Koying telah aktif melakukan perdagangan dengan daerah-daerah bagian barat dan selatan Sumatera serta dengan Tonkin dan Funan, tetapi perdagangan langsung dengan Cina belum dilakukan. Dilaporkan juga bahwa penduduk Ko-ying sangat banyak. Mereka menghasilkan mutiara, emas, perak, batu giok, batu kristal dan pinang.

Catatan Cina tidak menyebutkan secara jelas tentang dimana persisnya letak kerajaan Koying. Namun dijelaskan bahwa Koying terletak di Indonesia bagian barat, ke arah timur dari Tupo (Tebo) dan memiliki banyak gunung api. Berdasarkan data-data ini ahli sejarah menyimpulkan bahwa kemungkinan letak kerajaan Koying adalah di daerah sekitas Bukit Barisan Sumatera Tengah.

Keterangan tentang kerajaan Tupo dikemukakan oleh Ferand (1922) dalam Sartono (1992) berdasarkan sumber Cina yang ditulis oleh Fu-nan-t'u-su-chw'en berasal dari K'ang-tai bertahun 245-250. Lokasi kerajaan ini berdekatan berada di teluk Wen dan berjarak $5000 \mathrm{li}$ dari Koying. Sejarawan menyamakan Tupo dengan Tebo. Dengan demikian lokasi kerajaan Tupo berada di sekitar Muara Tebo sekarang.

Tentang Kandali menurut Sartono (1992), nama Kandali mulai dikenal melalui sumber Cina pada masa pemerintahan Hsiau-Wu (459-464 M). Sumber itu menceritakan bahwa raja Kandali yang bernama Sa-pala-na-lin-da menyuruh utusan yang bernama Taruda untuk pergi ke Negeri Cina sebagai utusannya.

Pada tahun 502, 519, dan 520 M kerajaan Kandali aktif mengirim utusannya ke Cina. Ketika itu Cina dipimpin oleh kaisar Wu dari Dinasti Liang. Dari catatan Cina diketahui bahwa kerajaan Kandali teletak di laut selatan dan adat kebiasaan penduduknya sama seperti di Campa dan di Kamboja. Hasil buminya meliputi bahan pakaian berbunga (tenun ikat), kapas, dan pinang bermutu tinggi.

Sumber Cina dari dinasti Ming menyamakan Kandali dengan San-fi-Tsi. Karena San-fo-tsi selalu dihubungkan dengan disamakan dengan Sriwijaya maka O.W Wolters menyatakan Kantoli terletak di Palembang. Tetapi Slamet Mulyana (2011) mengartikan bahwa Kandali sama dengan Kantoli yang terletak disekitar Jambi. Alasannya kata Kantoli diartikan sama dengan kata Kuntala atau Tungkal. Di bagian-bagian timur Sumatera terdapat Sungai Tungkal yang bagian hulunya bernama pengabuan yang bermuara di Muara/Kuala Tungkal. Jika merujuk pendapat Slamet Mulyana di atas dapat disimpulkan bahwa kerajaan Kantoli terletak di Kuala Tungkal. Namun setelah abad ke-7 catatan Cina tentang negara-negara yang mengrim utusan ke Negeri Cina tidak terdapat lagi kerajaan Kantoli. Nasib kerajaan ini tidak diketahui secara jelas.

Berita Cina pada masa Dinasti Tang abad 7 menyebutkan tentang datangnya utusan dari Mo-lo-you dan She-li-fo-shih pada tahun 644-645 M. Sejak waktu itu berita Cina tidak pernah lagi menyebut Kantoli. Sehubungan dengan itu Slamet Mulyana maupun Sartono menafsirkan bahwa Kantoli sudah ditaklukkan oleh Melayu, atau berganti nama dengan Melayu. Meskipun demikian tak tertutup pula kemungkinan bahwa Kantoli telah dikalahkan oleh Sriwijaya yang oleh berita dinasti Ming disebut San-fo-tsi.

Tentang Melayu dan Sriwijaya, keduanya adalah kerajaan merdeka yang punya kedaulatan setara dan sama-sama menjalin hubungan dengan Cina. Keterangan awal berasal dari catatan kronik Cina masa Dinasti Tang yang menyatakan tentang sebuah kerajaan bernama MoLo-Yu (Melayu) pada tahun 644 dan 645 masehi. Informasi lainnya berasal dari catatan perjalanan I-Tsing 
seorang pendeta Budha dalam perjalanannya dari Kanton menuju India dalam rangka upayanya menerjemahkan kitab suci agama Budha dari Bahasa Sanskerta ke bahasa Cina. Dalam perjalanannya yang berulang kali ini ia sempat mampir di Melayu dan Sriwijaya. Pada kedatangannya yang pertama tahun 672, ia tinggal di Sriwijaya selama 6 bulan dan di Melayu selama 2 bulan sebelum ia meneruskan perjalanan ke India (Mulyana, 2011).

Tentang Melayu dikatakannya bahwa bandar ini adalah bandar penting terletak di tepi selat Malaka antara Sriwijaya dan Kedah. Pelabuhannya ramai dikunjungi oleh kapal-kapal sambil menunggu angin yang baik, atau sebelum melanjutkan perjalanan. Banyak sejarawan sependapat bahwa pusat kerajaan pada masa itu adalah di daerah kota Jambi sekarang. Ia datang lagi ke Sriwijaya tahun 685 dan kembali ke Cina 4 tahun kemudian untuk mencari pembantu dalam upaya menyelesaikan pekerjaannya. Tetapi ketika ia datang lagi ke Sriwijaya tahun 692 dikatakannya bahwa Melayu sekarang telah menjadi Sriwijaya. Dengan demikian berarti sejak masa itu kerajaan Melayu telah menjadi bagian dari kerajaan Sriwijaya (Hall, 1988).

Kerajaan Melayu kembali muncul sebagai negara merdeka setelah Sriwijaya mengalami kemunduran disebabkan peperangannya dengan kerajaan Cola dari India Selatan. Berdasarkan sumber sejarah terkait ekspedisi Pamalayu yang dilancarkan Kartanegara pada akhir abad 13 diketahui bahwa pusat kerajaan Melayu terletak di Dharmasraya, suatu daerah yang termasuk provinsi Sumatera Barat sekarang. Ketika Adityawarman menjadi penguasa tertinggi Melayu pada abad 14 pusat kerajaan dipindahkan ke Pagaruyung yang merupakan daerah inti kebudayaan Minangkabau daerah yang terletak di pedalaman Sumatera Barat.

Baru abad 15 di Jambi berdiri lagi sebuah kerajaan yang didirikan oleh Puteri Selaras Pinangmasak yang merupakan puteri dari Raja Kerajaan Pagaruyung. Kerajaan Jambi bediri pada tahun 1480 dan bertahan hingga keberadaannya di bubarkan oleh Belanda pada tahun 1906.

Keberadaan kerajaan Jambi yang disebut terakhir sangat menarik untuk dibahas. Dalam konteks periodesasi sejarah Indonesia, masa eksistensi kerajaan Jambi berada dalam sebuah rentang waktu yang disebut kurun niaga.. Masa ini ditandai dengan peran aktif kerajaan-kerajaan di sepanjang jalur perdagangan yang terbentang mulai dari Iskandariah dipantai Laut Tengah dan kota pelabuhan Kanton di sebelah timur. Para ahli sejarah mengatakan masa ini adalah masa kemakmuran bagi kerajaan-kerajaan tersebut.

Sehubungan dengan uraian di atas maka rumusan masalah yang diajukan dalam tulisan ini adalah, bagaimanakah kedudukan kerajaan Jambi dalam jaringan perdagangan antar bangsa ? Secara spasial pembahasan topik ini mencakup bahasan tentang eksistensi kerajaan Jambi dalam dimensi ekonomi dan perdagangan.
Sementara batasan temporalnya adalah rentang waktu antara tahun 1480 dan 1834. Batasan ini ditetapkan karena dalam rentang masa ini kerajaan-kerajaan di Nusantara terlibat aktif dalam jaringan perdagangan antar bangsa. Angka tahun 1480 adalah batasan awal yang merupakan waktu berdirinya Kerajaan Jambi. Sedangkan tahun 1834 adalah waktu disepakatinya sebuah perjanjian antara Jambi dan Belanda, yang berkonsekuensi berkurangnya secara drastis kedaulatan Jambi dalam bidang ekonomi dan perdagangan.

Selain bertujuan menjelaskan keberadaan Kerajaan Jambi dalam jaringan perdagangan antar bangsa selama kurun waktu tersebut di atas,, Tulisan didorong oleh keadaan masih kurangnya hasil kajian tentang sejarah lokal Jambi, terutama masalah yang menyangkut dimensi ekonomi dan perdagangan pada masa modern awal.

Dengan cara menggali dan penelusuran kembali dan dilanjutkan dengan analisis objektiv terhadap faktafakta sejarah, tulisan ini diharapkan dapat memperkaya khasanah pengetahuan, serta menjadi refleksi dan bahan pertimbangan bagi instansi terkait dalam mengambil keputusan atau kebijakan terutama apabila hal demikian terkait dengan persoalan kesejarahan.

\section{Kerangka Teoritis}

Sebagai kerangka analisis tulisan ini menggunakan teori set of sets yang digunakan oleh K.N Chaudhuri dalam membahas jalur perdagangan Samudera Hindia. Menurutnya sejarah Asia antara abad 7 hingga abad 18 adalah suatu proses sejarah yang berlangsung lebih dari satu milinium, dimana laut lahan subur, gunung-gunung dan gurun, merupakan elemenelemen dasar dalam suatu kawasan tempat terjadi interaksi antara, para pelaut, para nomad dan para petani. Pemikiran seperti itu memungkinkan adanya suatu prinsip dimana setiap elemen dari berbagai set seperti samudera Hindia, orang-orang Arab, orang-orang India, orang-orang Cina dan lain sebagainya dipadukan dalam pola sejarah yang sama. Jalur ini dikenal dengan jalur sutera berfungsi menyalurkan produk-produk dari timur ke Barat. Alat utamanya adalah "karavan" yaitu rombongan onta dalam jumlah yang sangat besar (Leirissa, 1997)

Terbentuknya jalur perdagangan transkontinental yang membentang di Asia Tengah yang menghubungkan Chang-an (ibukota Cina sejak abad 17 hingga abad 13) dengan wilayah-wilayah sekitar laut Kaspia, serta dengan Mesopotamia, dan pelabuhan Antiochia di pantai Laut Tengah, adalah satu adalah satu pola sejarah. Jalur ini dikenal dengan jalur sutera, berfungsi menyalurkan produk-produk dari timur ke barat. Alat utamanya adalah "karavan" yaitu rombongan onta dalam jumlah yang sangat besar (Leirissa, 1997) Demikian pula halnya dengan jalur laut yang menghubungkan negeri pantai Laut Tengah di barat dengan dengan Cina di sebelah timur, melalui Laut Merah, Teluk Parsi, Samudera 
Hindia, Selat Malaka, Selat Sunda, dan Laut Cina Selatan. Sejarawan menyebut jalur ini dengan sebutan jalur pelayaran niaga karena berfungsi sama dengan jalur sutera.

Berdasarkan teori tersebut kemunculan kerajaan Jambi dapat dihubungkan dengan keberadaan Selat Malaka dan Samudera Hindia yang berfungsi sebagai jalur pelayaran niaga tersebut. Jalur perdagangan itu dipengaruhi oleh sistem angin di Asia tropis (Reid, 1999). Keteraturan itu dimanfaatkan oleh para pemilik kapal untuk kepentingan pelayaran. Apabila hendak melakukan pelayaran jarak jauh, para pemilik kapalberusaha mengurangi resiko pelayaran dengan cara menentukan waktu yang baik dan mengikuti arah angin. Pada bulan Januari-Februari dapat dipastikan bertiup angin utara yang dimanfaatkan oleh kapal-kapal Cina, Jepang, dan Ryukyu untuk berlayar ke selatan. Mereka kembali ke utara ketika bertiup angin dari arah selatan ada bulan Juni, Juli dan Agustus. Kapal-kapal Arab dan India akan berlayar ke Nusantara dengan memanfaatkan angin musim barat antara bulan April hingga Agustus. Kebanyakan dari mereka tinggal untuk berdagang sebari menunggu datangnya angin musim timur dan datangnya kapal-kapal Cina antara bulan Desember hingga April. Sejak abad 10 tertadi perubahan terhadap tatanan kontstan sistem pelayaran perdagangan. Untuk mengurangi waktu dan resiko pelayaran, perdagangan yang sebelumnya dilakukan secara jarak jauh dengan menggunakan kapal kecil berubah menjadi pelayaran jarak dekat menggunakan kapal yang lebih besar. Menurut Anthony Reid pelayaran yang berdasarkan angin musim dan perubahan sistem pelayaran pergangan inilah yang mengakibatkan lahirnya bandar-bandar perdagangan. Memperkuat pendapat Reid ini O.W Wolters mengatakan bahwa munculnya kerajaankerajaan masa awal di Asia Tengara (termasuk Jambi) merupakan akibat reaksi penduduk setempat yang menggunakan kesempatan yang diberikan oleh pedagang asing (Lapian, 1997). Rupanya penduduk lokal nusantara telah memanfaatkan jalur lalu lintas yang berbasis perdagangan itu untuk menciptakan wilayah-wilayah kekuasaan di sepanjang jalur perdagangan tersebut. Dalam konteks kerajaan Jambi, keterlibatannya dalam jaringan perdagangan ditopang oleh keberadaan sungai Batanghari yang menghubungkannya dengan kawasan hulu yakni daerah Minangkabau yang merupakan daerah subur yang sangat kaya dengan berbagai produk komoditas perdagangan (Asnan, 2016). Teori ini berlaku umum sebagai pendorong munculnya pusat-pusat kekekuasaan di sepanjang jalur strategis, akan tetapi mengenai eksistensi dan jatuh bangunnya pusat-pusat kekuasaan sangat ditentukan oleh dinamika internal kawasan seperti peperangan, dan penuklukanpenaklukan yang dilakukan oleh kekuatan yang lebih kuat. Sebagaimana halnya dengan munculnya kerajaankerajaan Turki di Asia Barat dan Moghul di India adalah buah dari ekspansi kekuasaan bangsa Mongol dari Asia Tengah (Leirissa, 1997).

\section{METODE}

Penelitian ini menggunakan metode deskriptif menggambarkan objek penelitian.

\section{HASIL DAN PEMBAHASAN \\ Jaringan Perdagangan Antar Bangsa}

Kegiatan perdagangan antar bangsa yang diikuti oleh munculnya jaringan perdagangannya telah ada sejak ratusan tahun sebelum Masehi. Sejarah China menerangkan bahwa pada tahun 138 SM, kaisar Han Wudi mengirimkan delegasi yang dipimpin oleh Zhang Qian ke Asia Tengah guna mencari sekutu melawan Xiong $\mathrm{Nu}$, suatu etnis nomad yang melakukan serangan dan penjarahan yang menyebabkan terganggunya jalur perdagangan. Misi itu menemui kegagalan karena Zhang Qian ditangkap dan dipenjarakan. Sepuluh tahun kemudian pimpinan delegasi itu berhasil melarikan diri dan kembali ke China. Meskipun misi itu mengalami kegagalan namun dia membawa informasi tentang tingginya minat perdagangan negeri-negeri sebelah barat karena mereka menginginkan produk-produk perdagangan yang tidak ada di negeri mereka terutama sutera. Faktor inilah kemudian menyebabkan timbulnya jaringan perdagangan yang besar yang terkenal dengan jalur sutera. Penamaan ini berasal dari komoditas perdagangan sutera yang merupakan produk dominan dalam dunia perdagangan sejak abad ke 2 sebelum Masehi. Kain sutera adalah produk perdagangan yang sangat mahal yang dikuasai oleh bangsa Cina selama ribuan tahun karena mereka berhasil menjaga kerahasiaan budidaya ulat sebagai sumber bahan pembuatan kain sutera. Sutera sangat ringan untuk dibawa namun bernilai setara dengan emas. Sutera diperdagangkan dalam bentuk mentah, dalam bentuk gulungan, permadani, pakaian dan karpet (idntimes.com 28 Agustus 2019, diakses tgl 14 Juli 2021).

Jalur Sutera adalah jalur perdagangan yang terbentang sepanjang ribuan kilometer menghubungkan dunia timur seperti China, India dan negeri-negeri kepulauan Nusantara, dengan dunia barat yaitu negerinegeri kawasan Timur Tengah dan Eropa. Jalur sutera terdiri dari dua jenis yakni jalur darat dan jalur laut. Jalur darat terdiri dari dua jalur yaitu jalur utara dan jalur selatan. Jalur utara terbentang dari kawasan Cina utara melalui daerah-daerah Bulgar-Kipchak di Asia Tengah, terus ke Semenanjung Kremia, kawasan Laut Hitam. Dari sini jalur terbagi dua, ada yang bersambung ke kawasan Eropa Timur hingga kota-kota Italia di Pantai Laut Tengah. Jalur lain melewati Laut Marmara hingga mencapai kota-kota di kawasan Laut Tengah seperti Genoa dan Venezia. Jalur Selatan mulai dari Cina Selatan melewati Turkestan di Asia Tengah, terus ke Khurasan, Anatolia, dan Antiokia, hingga kota-kota dikawasan Laut Tengah atau lewat darat darat ke Mesir 
dan Afrika Utara. Meskipun demikian bukan berarti rute perdagangan hanya membentang antara Cina di timur dan negeri-negeri kawasan Mediterania dan Eropa. Sejatinya rute perdagangan ini bercabang-cabang hingga kawasan Asia Selatan terutama India. Jalur laut membentang dari membentang dari kota-kota pelabuhan di Cina hingga ke ke Laut Tengah melewati kota-kota pelabuhan di sepanjang jalur seperti Aden dan Mekah di Laut Merah, Muscat, Hormuz, dan Bandar Abas, di Teluk Persia, Kambai dan Kalikut di Laut Arab, Satgaon di Teluk Benggala Malaka di Selat Malaka serta Kanton, Zaitun, dan Nanking di China (Leirissa, 1996).

Untuk Jalur darat perdagangan melewati sejumlah pegunungan dan dan hamparan gurun pasir yang membentang mulai dari Cina sebelah Barat, kawasan Asia Tengah, hingga kawasan Timur-tengah hingga Laut Mediterania. Perjalanan dagang biasanya dilakukan secara berombongan. Rombongan itu dalam bahasa Arab disebut kafilah, atau dalam bahasa Inggris disebut caravan. Pada umumnya perjalanan dilakukan pada saat musim dingin. Pertimbangannya selain lebih nyaman, pada musim dingin ketersediaan air di sepanjang rute perdagangan lebih banyak. Selain itu barang yang dijual di musim panas jauh lebih mahal daripada musim dingin.

Panjangnya bentang rute perdagangan mendorong munculnya kota-kota di sepanjang jalur tersebut. Umumnya kota-kota tersebut terletak di tempat-tempat strategis seperti daerah persimpangan jalur, serta daerahdaerah oasis. Dalam pengertian geografis oasis adalah daerah subur yang mengelilingi mata air atau sumber air lainnya dan memiliki banyak pohon di sekitarnya. Jika areanya luas dapat menjadi habitat hewan maupun manusia. Daerah oasis sangat penting dalam rute perdagangan dan transportasi daerah gurun, untuk dapat dijadikan tempat peristirahatan serta untuk memenuhi keperluan perjalanan terutama persediaan air. Di kotakota oasis itu biasanya terdapat sebuah tempat peristirahatan berbentuk seperti benteng yang disebut karavanserai. Di dalamnya banyak terdapat toko, penginapan. Selain itu terdapat pula semacam pasar ternak. Para kafilah banyak yang menukar hewan mereka yang sudah digunakan selama perjalanan dengan hewan baru yang masih segar dan lebih bertenaga. Kota besar dan paling terkenal di jalur sutera adalah Samarkand, yang terletak di Uzbekistan sekarang. Kota ini menjadi tempat berkumpulnya para pedagang dan rute utama sebelum meneruskan perjalanan dari dan menuju Eropa. Sisi lain yang menarik adalah, jika ada orang yang meninggal di Jalur Sutra ini, jasadnya dilemparkan ke suatu tempat yang bernama pemakaman langit (alam terbuka). Itu dilakukan karena mereka mempercayai bahwa kehidupan manusia selalu berbuat baik hingga akhir hayatnya, oleh karena itu tubuh mereka dibiarkan di alam terbuka agar dapat dimakan oleh burung.
Sungguhpun jalur perdagangan ini disebut jalur sutera bukan berarti sutera adalah satu-satunya produk komoditas yang diperdagangkan. Selain sutera para pedagang Cina juga memperdagangkan rempah-rempah, porselin, serta barang-barang lain seperti parfum, permata, karang, gading, bulu, bubuk mesiu, dan manikmanik kaca. Para pedagang Arab Timur Tengah dan Eropa membawa giok, anggur, hewan, pecah-belah, wol, dan gelas khas Mediterania untuk dijual atau barter.

Selain untuk keperluan perdagangan jalur ini juga digunakan untuk kepentingan lain seperti politik dan kebudayaan. Seorang sejarawan mengatakan bahwa jalur sutera menjadi tonggak awal bertemunya peradabanperadaban maju yang hidup pada zaman itu. Dalam sebuah novel, Life Along the Silk Road, dikisahkan seorang saudagar bernama Nanaivandak melintasi Jalur Sutra menuju Cina. Jalur ini ditempuh karena dua alasan, yakni kecintaan Nanaivandak pada pemandangan pegunungan dan bisnis yang harus dikelolanya. Selama 20 tahun, ia melawan para begundal yang tak jarang melakukan kekerasan kepada saudagar atau penjelajah yang melintasi jalur itu. Nanaivandak sempat berhenti di Chang'an untuk menjual sebagian minyak misik ( suatu minyak yang berasal dari keringat kijang gunung berkelamin jantan untuk keperluan supranatural ), kerajinan perak, dan batu mulia. Di sana, yang ia temui adalah pembeli dengan bahasa ibu berbeda. Dengan wajah dan gaya berpakaian tersendiri, tampilan Nanaivandak bisa dibedakan dari orang-orang bangsa Turki, Cina, dan Tibet yang tinggal di sana. Bertahuntahun kemudian, Jalur Sutra menjadi lazim di antara orang-orang Cina.

Dalam literatur lain, Doudou Diene yang menulis pembukaan dalam buku The Silk Roads: Highways of Culture and Commerce mengungkapkan, Jalur Sutra tak hanya terbentang untuk kepentingan bisnis, tapi juga jadi jalur cepat pembauran budaya Timur dan Barat. Sementara, Whitfield menggambarkan Jalur Sutra sebagai pertukaran arus di Asia Tengah, dari barang kasat mata hingga nilai-nilai yang dibawa manusia. Buddhisme dan Islam bertemu di berbagai tempat. Pada saat yang sama, perdagangan membuat berbagai negara mulai terhubung. Penemuan terbaru, informasi, dan bahasa saling merambat dari Timur dan Barat. Jalur Sutra pun jadi semacam wadah globalisasi perdagangan, budaya, dan gagasan.

Perdagangan juga membuka peluang transmisi agama. Buddhisme bahkan, merupakan keyakinan pertama yang dipraktikkan masyarakat Tukharistan (Afghanistan) dan Transoxiana (Uzbekistan dan Kazakhstan). Buddhisme tersebar melalui para misionaris dari India yang berjalan menuju Cina sambil menyampaikan ajaran Buddhisme. Dari India, Buddhisme kemudian menyebar ke Sri Lanka dan Benggala. Karena itu, tak heran jika patung-patung Buddha ditemukan di sepanjang Jalur Sutra. Ajaran- 
ajaran Pada biksu juga tak jarang tampak berada di Jalur Sutra untuk menyebarkan ajaran Buddhisme.

Buddhisme bertahan di dataran Tibet dalam waktu singkat di Asia Tengah sebelum Islam hadir di sana. Asia Tengah kemudian perlahan menjadi wilayah yang didominasi Islam dengan Transoxiana sebagai jantungnya di Timur. Perubahan di Asia Tengah membuatnya jadi pusat komunikasi yang menghubungkan Islam dengan lebih banyak kultur, negara, dan tradisi. Wilayah-wilayah Islam bermunculan yang disusul 'penaklukan' oleh para penguasa.

Pada masa Kekaisaran Mongol, ekspansi Islam lebih menjanjikan. Islam berhasil disebarkan ke wilayah pesisir India melalui para pedagang Arab dan diteruskan bangsa Turki ke utara. Penyebaran Islam yang dilakukan melalui dakwah damai para sufi dan penaklukan, membuat Muslim berhasil mendominasi jalur perdagangan dunia itu. Tak hanya Islam dan Buddhisme, Jalur Sutra juga turut membantu penyebaran agama Kristen (Republika.co.id, Selasa 14 Februari 2017 16:48. Diakses tgl 14 Juli 2021).

Sejak awal abad Masehi rute perdagangan mulai beralih ke laut. Terdapat sejumlah faktor yang menyebabkan bergesernya jalur perdagangan dari darat ke laut. Pertama, adalah faktor jarak. Jalur sutra merupakan jalur yang sangat panjang dan jauh. Apabila jalur ini ditempuh dari titik pangkal hingga titik terjauh akan memerlukan waktu yang sangat lama sehingga ketika barang sampai di tempat tujuan, barang yang dibawa kondisinya sudah kurang bagus. Namun faktor yang lebih menentukan adalah faktor politik dan keamanan. Jalur darat cukup rentan dengan situasi politik di sepanjang rute perdagangan.

Sejak abad 5 SM hingga abad $5 \mathrm{M}$, di dunia belahan barat terdapat dua kutub kekuatan besar yang mempengaruhi dunia perdagangan. Yang pertama adalah Yunani dan Romawi yang berpusat di Eropa dan kedua adalah Persia yang terletak di Asia Barat. Sedangkan di belahan timur adalah kekaisaran Cina yang kala itu dikuasai oleh dinasti-dinasti Zhou, Qin dan Han. Meskipun demikian bukan berarti seluruh masa itu daratan Cina yang amat luas itu dikuasai utuh oleh ketiga dinasti tersebut. Ada masa-masa dimana kawasan Cina terpecah dan diperintah oleh banyak kerajaankerajaan kecil.

Kaitannya dengan dunia perdagangan, perubahanperubahan politik seringkali diikuti oleh jatuh bangunnya kerajaan-kerajaan di sepanjang jalur perdagangan. Kondisi ini sering menyebabkan kegiatan perdagangan terganggu dan jalur yang dilalui menjadi tidak aman. Konflik antar kerajaan yang bertikai seringkali dimanfaatkan oleh suku-suku nomad untuk melakukan aksi perampasan karena kontrol atas mereka dari negara yang sedang berkonflik melemah. Dalam rentang waktu abad 1 hingga abad 7 terjadi lebih kurang 30 kali peperangan besar yang melibatkan Romawi dan Persia. Dalam rangkaian peperangan itu kedua pihak memperoleh kemenangan yang silih berganti. Ketika Persia beroleh kemenangan misalnya misalnya, mereka mengendalikan perdagangan sutera dan lain-lain di daerah-daerah yang mereka kuasai. Akibatnya pedagang dari Kekaisaran Romawi berupaya menghindari wilayah Persia dengan mengalihkan rute ke utara melewati wilayah Kaukasus dan melintasi Laut Kaspia. Sementara perdagangan yang luas terjadi melalui jaringan sungai yang melintasi stepa Asia Tengah. Namun, karena jaringan sungai tersebut memiliki tingkat air yang tidak sesuai, bahkan sering mengering maka rute perdagangan bergeser (Kompas.com 15/01/2020 diakses 26 Juli 2021).

Selain dua faktor yang dijelaskan terdahulu, faktor laut itu sendiri adalah yang paling utama. D.H Burger mengemukakan Sejumlah faktor penting yang mendorong munculnya sistem pelayaran niaga jarak jauh antara Laut Merah, India dan Tiongkok.. Pertama, sejak permulaan abad Masehi para pelaut mulai mengetahui jalan angin tropik yang bertiup secara teratur menurut musim yang menjadi dasar pelayaran hingga munculnya kapal api. Kedua, Semakin baiknya teknologi pelayaran dengan ditemukannya kapal-kapal yang dapat mengangkut orang dengan jumlah banyak yakni 600 hingga 700 orang. Dua faktor lainnya adalah faktor non laut, yakni terhentinya pasokan emas ke India dari Siberia akibat terjadinya perpindahan bangsa-bangsa yang merusak jalur perdagangan. Situasi itu menyebabkan permintaan India akan emas berpindah ke daerah-daerah timurnya. Selain itu perkembangan agama Budha juga dikatakan sebagai pendorong. Agama Buddha yang ajarannya tidak mengenal sistem kasta dan prasangka-prasangka kebangsaan yang tadinya menghalang-halangi perniagaan dengan bangsa asing (Burger, 1962).

Jalur sutera (laut) dihubungkan melalui Samudera Hindia dan Laut Cina Selatan. Samudera Hindia yang dimaksud adalah dalam arti luas yakni meliputi Samudera Hindia itu sendiri dan laut-laut maupun selatselat yang mengitari pulau-pulau di sekitar Samudera Hindia. Laut yang menghubungkan wilayah Timur Tengah dan Asia itu memiliki berbagai ciri yang relatif tidak berubah dalam jangka waktu ribuan tahun. Faktor laut serta unsur-unsur kehidupan yang ada di dalamnya, lalu ketinggian atau volumenya yang terus bertambah, berikut salinitas atau kadar garam yang relatif sama, serta arus-arus laut tertentu dapat dipelajari dan dimanfaatkan untuk kepentingan pelayaran.

Dengan demikian unsur geografis itu menyebabkan jalur pelayaran tidak mudah berubah, dan kalaupun mengalami perubahan akan memakan waktu ratusan hingga ribuan tahun. Umpamanya adalah perubahan jalur pelayaran yang disebabkan oleh pertumbuhan karang yang menutup jalur pelayaran tertentu sehingga perlu dicari jalur lain. Selain itu garis pantai serta muara sungai juga tidak mudah berubah, sehingga pemukiman di pantai juga bisa berusia panjang. 
Unsur-unsur geografi inilah yang memungkinkan munculnya suatu sistem pelayaran niaga yang juga bertahan ratusan tahun. Tentang unsur geografis yang memiliki ciri perubahan skala panjang ini oleh sejarawan Fernan Braudel disebut faktor longue duree Akan tetapi menurut Braudel selain perubahan skala panjang, juga ada ciri perubahan-perubahan lain yang disebutnya perubahan jangka menengah dan perubahan jangka pendek (Leirissa, 1996).

Di antara unsur geografi yang membatasi perubahan jangka panjang itu yang terpenting adalah sistem angin. Sedangkan angin adalah faktor utama yang mana teknologi pelayaran pada masa itu sangat bergantung pada angin. Kawasan Samudera Hindia mengenal sistem angin yang secara konsisten mengalami perubahan selama enam bulan sekali. Keadaan itu ternyata menciptakan prasarana yang penting bagi pelayaran niaga. Para pelaut dan pedagang dapat memperhitungkan kegiatan mereka dengan tepat sesuai dengan irama pertukaran arah angin yang konsisten itu.

Antara bulan April sampai bulan Oktober angin bertiup dari arah timur ke barat dan di Nusantara dinamakan Musim Timur. Kemudian dari bulan Oktober hingga April arah angin merubah dari barat ke timur yang di nusantara disebut Musim Barat. Dari musim itulah orang Eropa mendapat kata monsoon untuk sistem angin yang khas itu. Meskipun begitu tentu saja ada juga variasi-variasinya. Pertama-tama sudah bulan Agustus hingga bulan November muncul tanda-tanda akan terjadinya perubahan arah itu sehingga bulan itu sering dinamakan musim pancaroba pada musim timur. Demikian pula pada bulan April hingga Mei disebut masa pancaroba Musim Barat.

Perubahan arah angin ini dikaitkan dengan letak semu matahari. Antara bulan April hingga Oktober matahari terletak pada bagian utara bola bumi, sehingga Australia mengalami musim dingin dan di Eropa terdapat musim panas. Dalam keadaan itu di kawasan Eropa terjadi depresi dan kekosongan itu diisi oleh angin yang bertiup dari arah Australia, maka terjadilah angin musim timur. Sebaiknya antara bulan Oktober hingga April letak semu matahari berada di belahan bumi selatan sehingga Australia mengalami musim panas dan Eropa musim dingin. Musim dingin di Eropa disertai tekanan udara yang tinggi dan keadaan sebaliknya di Australia melemah. Akibatnya angin bergerak dari arah Eropa/ Asia ke Australia maka terjadilah angin musim Barat.

Di Nusantara yang dilalui garis khatulistiwa polanya sebenarnya tidak sesederhana itu dan jauh lebih rumit. Dikarenakan rotasi bumi maka sistem angin musim di khatulistiwa mengalami perubahan lagi. Musim timur akan beralih menjadi musim barat ketika melintasi khatulistiwa. Keadaan ini sangat menguntungkan pelayaran niaga di Nusantara karena para pelaut bisa menempuh dua arah baik pada musim barat maupun musim timur ketika mereka melewati khatulistiwa. Arus-arus laut yang bersumber dari Samudera Pasifik dan Samudera Hindia, maupun Laut Cina Selatan juga mempengaruhi pelayaran niaga sehingga menambah kerumitan jalur- jalur pelayarannya. Namun keadaan tersebut tidak terlalu menyulitkan pelaut Nusantara karena di kawasan ini terdapat ribuan pulau yang dapat memudahkan navigasi sehingga mengurangi kesulitan yang disebabkan oleh unsur-unsur tersebut di atas Para pelaut Nusantara dapat menjadikan ciri-ciri daratan (garis pantai) sebagai patokan pelayaran. Pelayaran umumnya berlangsung menyusuri pulau demi pulau ( pelayaran pantai ) sehingga para pelaut dapat menemukan ciri-ciri daratan untuk menentukan posisinya di laut (Leirissa, 1996).

Sistem navigasi di atas berbeda dengan pelayaran di laut lepas, umpamanya dari Teluk Persia ke India serta dari India ke Nusantara, atau dari Nusantara ke Cina. Para pelaut akan menempuh jalur laut lepas, dan untuk itu mereka harus mahir menggunakan sistem navigasi perbintangan dengan perhitungan-perhitungan yang cukup abstrak.

Memasuki abad ke 10 dan 11 terjadi perubahan terhadap tatanan-tatanan konstan sistem pelayaran niaga. Menurut Chaudhuri sebelum abad 10 pelayaran niaga dilakukan dengan menempuh satu jalur yang tidak terputus-putus dari timur ke barat atau sebaliknya. Para pelaut dari Timur Tengah yang berlayar ke Nusantara atau ke China menempuh jarak itu sekaligus atau kadang-kadang terpaksa berlabuh di pelabuhanpelabuhan tertentu untuk menunggu angin. Sebelum abad 10 belum ada pelabuhan-pelabuhan yang mempunyai fasilitas yang memadai untuk dijadikan tempat persinggahan dalam jalur niaga yang panjang itu.

Tetapi sejak abad 10 dan 11 muncul apa yang disebut emporium yaitu kota-kota pelabuhan yang dilengkapi dengan berbagai fasilitas yang memberi kemudahan pada para pelaut untuk memperbaiki kapalkapalnya, sekaligus memudahkan para pedagang untuk berdagang. Berbagai fasilitas perdagangan mulai dari gudang-gudang, penginapan, hingga fasilitas kredit mulai tersedia di kota-kota pelabuhan tertentu sehingga menjadikannya sebagai emporium.

Berbagai emporium bermunculan di sepanjang jalur perdagangan seperti Mocha di Laut Merah, Muscat, Hormuz, dan Bandar Abas di Teluk Persia, Kambai dan Kalikut di Laut Arab, Satgaon di Teluk Benggala, Malaka di Selat Malaka, serta Kanton, Zaitun dan Nanking di Laut Cina. Dalam setiap emporium terdapat pengusaha-pengusaha yang memiliki modal yang besar. Bisnis para pengusaha itu selain bergerak dalam kegiatan jual beli produk komoditas, juga menyediakan fasilitas kredit, gudang-gudang dan penginapan. Selain itu mereka juga memiliki kapal-kapal untuk dipakai sendiri atau untuk dijual maupun untuk disewakan untuk digunakan dalam ekspedisi-ekspedisi dagang ke berbagai emporium lain (Leirissa, 1996). 
Setelah munculnya berbagai emporium di sepanjang jalur pelayaran niaga menyebabkan sistem pelayaran niaga jarak jauh tidak lagi dilakukan secara langsung atau tidak terputus-putus. Ketersediaan berbagai fasilitas di berbagai emporium mendorong perdagangan dapat dilakukan dari satu emporium ke emporium lainnya. Para pedagang Arab apabila mereka hendak membeli atau memasarkan barang mereka ke Cina tidak lagi harus melakukan pelayaran langsung ke Cina. Mereka dapat membeli barang-barang produk Cina di Kalikut atau di Malaka, karena barang-barang itu telah dibawa oleh pedagang Cina ke Malaka.

Sistem pelayaran niaga jarak pendek ini selanjutnya semakin berkembang karena selain ditopang oleh ketersediaan fasilitas emporium dapat meminimalisir resiko di laut selama melakukan pelayaran. Resiko itu antara lain faktor cuaca yang dapat menimbulkan badai dan gelombang laut yang bisa menyebabkan kecelakaan, serta batu karang yang dapat menyebabkan kerusakan kapal. Selain itu sistem pelayaran yang lebih pendek dapat pula menghemat waktu dan tenaga, sehingga kegiatan perdagangan dapat dilakukan lebih efektif.

\section{Jambi Dalam Jaringan Perdagangan Antar Bangsa}

Untuk melihat kedudukan Jambi dalam perdagangan antar bangsa ada baiknya terlebih dahulu pola perdagangan yang menjadi ciri-ciri umum sistem perdagangan negeri-negeri di Nusantara dalam rentang permulaan abad Masehi hingga abad 19. Hal ini penting untuk mempermudah pemahaman karena hampir semua ciri umum perdagangan Nusantara melekat pada sistem perdagangan yang ada di Jambi.

Pola dan kedudukan Jambi dalam jaringan perdagangan dipengaruhi oleh letak geografisnya yang strategis yakni terletak di jalur perdagangan internasional. Posisi itu menjadikan Jambi sebagai suatu wilayah yang terlibat aktif dalam kegiatan perdagangan antar bangsa sejak masa periode awal keterlibatan negeri-negeri Nusantara. Umumnya sejarawan mengatakan bahwa keterlibatan negeri-negeri Nusantara dalam jaringan perdagangan internasional dimulai sejak permulaan abad masehi. Sebagaimana yang disinggung pada bagian terdahulu, kondisi jalur sutera yang kurang aman akibat sering terganggu disebabkan berbagai peperangan antara bangsa yang dilewati jalur tersebut, serta terjadinya arus gelombang perpindahan bangsabangsa secara besar-besaran (Burger, 1962), menyebabkan jalur perdagangan antar bangsa berganti dengan menggunakan jalur laut. Munculnya pengetahuan tentang sistem angin serta didukung oleh kemajuan teknologi dalam bidang perkapalan yang bisa mengangkut muatan orang maupun barang dalam jumlah besar menyebabkan jalur perdagangan laut semakin berkembang. Kondisi itu telah mendorong munculnya kerajaan-kerajaan emporium di Nusantara yang berperan aktif dalam perdagangan internasional.
Prosesnya menurut Menurut Van Leur, sekelompok orang di bawah otoritas kaum aristokrat menumpuk kekayaan dari perdagangan swasta (atau pribadi), pajak-pajak perdagangan transit, perang dan melakukan penjarahan merupakan dasar utama bagi kekuatannya. Kekuatan bersenjata kerajaan yang terdiri dari milisi yang dilengkapi oleh bangsawan (selain pasukan dari penguasa itu sendiri ) membuat organisasi militer yang membentuk dasar bagi hubungan antara penguasa dan rakyat di pelabuhan-pelabuhan (Van Leur, 2015).

Meskipun demikian hingga abad ke 3 belum ada keterangan sejarah yang menyebutkan keterlibatan Jambi maupun negeri-negeri Nusantara lainnya dalam jaringan perdagangan tersebut. Catatan pertama yang menyebutkan keterlibatan negeri Nusantara adalah tentang negeri Ko-ying dibuat oleh K'ang-tai dan Wanchen dari wangsa $\mathrm{Wu}(222-280)$. Keterangan tentang negeri yang sama juga dimuat dalam ensiklopedi T'ungtien yang ditulis oleh Tuyu tahun 375. Sumber-sumber tersebut menerangkan bahwa di kerajaan Ko-ying ada gunung api dan di selatannya ada sebuah teluk bernama Wen. Dalam teluk itu ada pulau bernama Pu-Lei. Penduduk yang mendiami pulau itu semuanya telanjang bulat, laki-laki maupun perempuan, kulit berwarna hitam kelam, giginya putih-putih dan matanya merah. Mereka melakukan perdagangan secara barter dengan para penumpang kapal yang berlabuh di Koying. Dagangan mereka adalah ayam, babi serta buah-buahan yang mereka dipertukarkan dengan berbagai benda logam. Memperhatikan ciri-ciri fisik tersebut dapat diartikan bahwa mereka bukan termasuk rumpun Melayu tetapi mungkin lebih mirip rumpun Proto-Negrito yang sebelumnya telah menghuni daratan Sumatera. Dari sumber India dan Funan diketahui bahwa pada abad ke 3 kerajaan Koying telah aktif melakukan perdagangan dengan daerah-daerah bagian barat dan selatan Sumatera serta dengan Tonkin dan Funan, tetapi perdagangan langsung dengan Cina belum dilakukan. Dilaporkan juga bahwa penduduk Ko-ying sangat banyak. Mereka menghasilkan mutiara, emas, perak, batu giok, batu kristal dan pinang.

Selain itu ada pula catatan tentang Tupo juga diperoleh informasi berdasarkan catatan sejarah Cina yang ditulis oleh Fu-nan-tu-su-chwen berasal dari Kangtai tahun 245-250M. Transliterasi tuponim menunjukan Tupo sama dengan Muara Tebo. Catatan Cina tidak menyebutkan secara jelas tentang dimana persisnya letak kerajaan Koying dan Tupo. Namun dijelaskan bahwa Koying terletak di Indonesia bagian barat, berjarak sejauh $5000 \mathrm{Li}$ ke arah timur dari Tupo dan memiliki banyak gunung api. Namun jika benar bahwa Tupo adalah transliterasi dari Muara Tebo maka tentulah letak kedua kerajaan itu di provinsi Jambi sekarang.

Informasi lainnya adalah mengenai Kerajaan Kandali yang diketahui melalui sumber Cina pada masa pemerintahan Hsiau-Wu (459-464 M). Sumber itu 
menceritakan bahwa raja Kandali yang bernama Sa-pala-na-lin-da menyuruh utusan yang bernama Taruda untuk pergi ke Negeri Cina sebagai utusannya. Pada tahun 502, 519, dan 520 M kerajaan Kandali aktif mengirim utusannya ke Cina. Ketika itu Cina dipimpin oleh kaisar Wu dari Dinasti Liang. Dari catatan Cina diketahui bahwa kerajaan Kandali terletak di Laut Selatan dan adat kebiasaan penduduknya sama seperti di Campa dan di Kamboja. Hasil buminya meliputi bahan pakaian berbunga (tenun ikat), kapas, dan pinang bermutu tinggi (Sartono, 1992). Mengenai letak Kantoli terdapat perbedaan pendapat di antara para ahli. J.J Boeles mengatakan di Thailand Selatan karena didasarkan pada adanya sebuah desa yang bernama Kanthuli. Namun pendapat ini ditentang oleh O.W Wolter karena di desa itu sama sekali tidak ditemukan keramik Cina pada zaman Sung. Wolter cenderung menempatkan Kantoli di Palembang. Pendapat umum para ahli mengatakan bahwa Kantoli terletak di pantai timur Sumatera Selatan yang wilayahnya meliputi Palembang dan Jambi. Namun jika berpijak pada pendapat Coedes yang mendasarkan pendapatnya pada catatan sejarah Dinasti Liang, maka dapat dikatakan bahwa Kantoli itu berpusat di Jambi (Coedes, 2010).

Menurut A.B Lapian (1992) keterangan mengenai daerah Asia Tenggara khususnya tentang wilayah sekitar selat Malaka mulai meningkat setelah abad 5. Sejak kurun ini mulai banyak berita berasal dari pengunjungnya sendiri. Sebelumnya berita yang diperoleh berasal dari sumber sekunder. Ini membuktikan bahwa pelayaran orang Cina ke daerah ini semakin banyak dan mencerminkan pula peningkatan keramaian pelayaran di kawasan ini. Jika sebelumnya dalam jalur perdagangan antara Cina, India, dan Asia Barat, kawasan Asia Tenggara dan negeri-negeri yang terletak di selat Malaka hanya berperan sebagai tempat singgah, kini pengunjung asing itu sengaja berlayar untuk berdagang, yaitu untuk mempertukarkan barang impor seperti kain sutera, dan keramik dari Cina, serta tekstil dari India dan sebagainya dengan hasil kepulauan Indonesia berupa rempah-rempah, kayu wangi, dan lainlain.

Berita dari I-Tsing abad ke 7 memberi keterangan yang lebih jelas tentang negeri-negeri di Asia Tenggara terutama tentang Sriwijaya dan Melayu. Kendati I-Tsing tidak secara spesifik bercerita tentang masalah perdagangan -- karena memang perjalanannya bukan untuk kegiatan perdagangan - tetapi keterangannya dapat memberi gambaran tentang daerah-daerah yang disinggahinya serta memberi informasi tentang lamanya waktu yang diperlukan untuk berlayar dari suatu daerah ke daerah lainnya. Dari keterangan I-Tsing diketahui bahwa pada abad 7 terdapat dua kerajaan penting di Sumatera yakni Melayu dan Sriwijaya, dan dari dia pulalah diketahui bahwa pada tahun 685 kerajaan Melayu telah ditaklukan oleh kerajaan Sriwijaya. Tentang pelayaran dikatakannya bahwa lama pelayaran
Sriwijaya dan Melayu ( Jambi ) 15 hari, dan dari Melayu ke Kedah memakan waktu 15 hari. Pelayaran dari Kedah ke Nalanda ditempuh selama dua bulan (Poesponegoro, 1992).

Dari data teknik navigasi yang dihimpun oleh Van Leur diketahui bahwa pelayaran dari Kanton ke Sriwijaya abad 7 memakan waktu 21 hari sebulan, dan lebih dari sebulan. Pada abad 9 memakan waktu beberapa minggu dan pada abad 10 memakan waktu sebulan. Pada abad 17 pelayaran dari Palembang ke Kanton membutuhkan waktu 39 hari. Menurut Van Leur data-data itu ada yang kurang tepat tetapi juga tergantung keragaman kapal yang digunakan (Van Leur, 2015). Selain itu ditentukan pula oleh rute yang ditempuh. Dalam perjalanannya ke Sriwijaya yang berulang kali, I-Tsing menempuh rute laut lepas dan menyusur pantai. Rute laut lepas memakan waktu lebih singkat ketimbang rute menyusur pantai. Rute laut lepas dari Kanton ke Sriwijaya menghabiskan waktu 20 hari. Sedangkan menyusur pantai ditempuh selama satu bulan (Mulyana, 2011).

Hingga abad 15 data-data tentang aktivitas perdagangan tidak banyak ditemukan. Tidak ditemukan catatan-catatan tentang angka volume perdagangan antara Jambi dengan pedagang asing seperti Arab, India, dan Cina, maupun dengan mitra dagangnya sesama pedagang Nusantara. Meskipun demikian keterangan tentang kapal-kapal yang digunakan setelah abad masehi mengatakan bahwa yang digunakan adalah kapal-kapal yang yang cukup besar berbobot 300 ton, dan mampu mengangkut penumpang sebanyak 600 hingga 700 orang (Burger, 1962). Mungkinkah itu menunjukan volume perdagangan yang besar ? Hampir semua kapal yang berlayar pada masa itu adalah kapal dagang. Tentu saja mereka tak akan berlayar jika muatan yang ada di kapal berjumlah sedikit karena akan merugikan bila tidak sesuai dengan pengorbanan dan resiko pekerjaan. Akan tetapi ukuran besar muatan kapal tentu belum cukup untuk menunjukan volume perdagangan karena besaran angka jumlah kapal yang keluar masuk pelabuhan Jambi juga sangat menentukan.

Van Leur berusaha menggambarkan jenis-jenis barang dagangan negeri-negeri Nusantara dari abad 1 hingga abad 15, yang diambilnya dari berbagai sumber. Mutiara, batu mulia, barang langka, emas dan kain sutera adalah barang-barang dalam perdagangan laut ke Cina pada akhir abad 1. Keterangan ini diperolehnya dari Ferrand. Tetapi untuk kain sutera keterangan ini meragukan karena Sutera justru berasal dari Cina, bukan sebaliknya. Hadiah-hadiah kedutaan Sriwijaya kepada kaisar Cina pada abad 7 adalah perak, mutiara, minyak kamper wewangian dan produk lainnya. Dari Krom, Van Leur mencatat barang-barang Indonesia yang dikirim ke Arab pada abad 10, adalah kayu gaharu, kamper, kayu cendana, gading timah kayu hitam, kayu sapan, rempah. Termasuk juga hadiah Sriwijaya kepada kaisar Cina seperti gading, kemenyan, air mawar, kurma, buah 
persik, gula putih, cincin kristal, botol kaca, nafta, koral, kain katun, cula badak, wewangian dan bumbu dapur. Semua barang itu merupakan barang khusus perdagangan internasional Sriwijaya dan tentu saja tidak semua barang dagangan atau hadiah itu merupakan produk yang dihasilkan sendiri oleh Sriwijaya. Sebagian di antaranya seperti kurma, kain katun adalah berupa barang yang dihasilkan oleh negeri Arab dan India.

Pada tahun 980 seorang pedagang Sriwijaya tiba di Shantou dengan kargo berisi wewangian, obat-obatan, bumbu dapur, gading dan cula badak. Di antara barangbarang yang dikirim ke Arab pada abad 12 adalah timah. Barang-barang perdagangan internasional di Indonesia pada abad 13, timah, gading, mutiara, tempurung penyu, kamper kayu gaharu, cengkeh, buah pala, kayu cendana, air mawar emas, perak, porselin, sutra, gula, besi, minuman keras, beras, lengkuas, kelembak. Barang dagangan Indonesia. Barang-barang dagangan Indonesia pada abad 14 adalah beras, garam, merica, kain katun, burung beo, koin perunggu Cina, emas, perak, pinang, ukiran kayu, mutiara, cengkeh, kayu cendana, porselen. Pada abad 15, barang-barang dagangan Indonesia terdiri dari, budak kulit hitam, mutiara, merica, bulu kepala burung enggang, kayu yang telah dipernis, kayu gaharu, kapur barus, damar, timah, kayu hitam, merica, sulfur, kayu ceri, kayu cendana, kayu sapan, berlian, rempahrempah, tempurung penyu, burung beo, porselen, rusa, sutra, manik-manik.

Meskipun semua barang-barang dagangan Indonesia ataupun yang diperdagangkan di Indonesia tidak semuanya berasal dari Jambi. tapi banyak di antaranya adalah barang-barang berasal dari Jambi atau daerah Minangkabau yang merupakan daerah subur dan kaya akan barang tambang yang terletak di kawasan sungai Batanghari, atau memang barang-barang produk luar yang diperdagangkan di Jambi. Hal itu karena pelabuhan Jambi tergolong pelabuhan internasional tertua di Nusantara dan memperdagangkan banyak produk karena daerah hulu dan pedalamannya Minangkabau adalah daerah yang kaya akan produk dagangan seperti emas, merica, kayu, dan barang-barang hasil hutan. Semua komoditas itu tergolong pada yang terpenting atau primadona dalam perdagangan. Hal itu mendorong kontinuitas peranan Jambi dalam perdagangan antar bangsa. Ada kalanya peran dan kedudukan itu begitu penting, tetapi pada penggalan masa yang lain peran itu begitu kecil dan dipandang sebelah mata terutama oleh bangsa lain.

Jika ditarik secara kronologis maka kelihatan peran itu mengalami pasang surut. Sebelum abad 7 pelabuhan Jambi dapat dikatakan yang terpenting di Nusantara. Hal ini didasarkan catatan-catatan aktivitas perdagangan kerajaan-kerajaan yang oleh ahli sejarah dikatakan berpusat di Jambi. Kerajaan-kerajaan itu adalah Koying dan Tupo pada abad 4 dan 5, yang mata perdagangannya adalah mutiara, emas, perak, batu giok, batu kristal dan pinang. Selanjutnya Kandali atau
Kantoli abad 5 dan 6, secara teratur mengirim utusannya ke Cina. Hasil buminya meliputi bahan pakaian berbunga (tenun ikat), kapas, dan pinang bermutu tinggi. Berikutnya adalah Kerajaan Melayu yang menurut Soekmono dan Slamet Mulyana mempunyai posisi lebih strategis daripada Sriwijaya.

Menurut Soekmono pelabuhan Sriwijaya tersisih dari lalu-lintas perahu dari Tiongkok ke Selat Malaka dan kebalikannya. Jambi mempunyai kedudukan yang jauh lebih penting daripada Palembang, yang hanya disinggahi oleh kapal-kapal yang melewatinya dalam pelayaran antara Selat Malaka dan pulau Jawa saja. Alasan ini disandarkan pada keterangan I-Tsing yang mengatakan ia berangkat dari Tamralipti (India) menuju Kedah. Singgah di situ sampai musim dingin. Dengan menumpang perahu raja ia berangkat dari Kedah menuju Melayu yang sekarang telah menjadi bagian Sriwijaya. Pelayaran itu memakan waktu sebulan. Dikatakannya lagi, umumnya perahu datang di negeri Melayu pada bulan kedua. Dia tinggal di Melayu sampai pertengahan musim panas, lalu berangkat ke Utara menuju KwangTung (Kanton). Keterangan I-Tsing menunjukan bahwa dalam perjalanan pulangnya dari India ke Cina dia tidak melewati pelabuhan Sriwijaya. Soekmono juga memberi alasan geografis dengan menjelaskan bahwa Jambi letaknya menghadap ke laut bebas, sedangkan Palembang pada suatu selat saja yaitu Selat Bangka. Dengan demikian pelabuhan Jambi jauh lebih penting dari pada pelabuhan Palembang, dan menurut Slamet Mulyana, itulah yang menyebabkan Sriwijaya menganeksasi Kerajaan Melayu. (Mulyana, 2011).

Peran Jambi mengalami kemunduran setelah Kerajaan Melayu ditaklukan oleh Sriwijaya tahun 683. Dengan mempunyai angkatan laut yang kuat memungkinkan bagi Sriwijaya untuk mengendalikan jalur perdagangan di kawasan Asia Tenggara terutama di sekitar wilayah selat Malaka. Sriwijaya memaksa kapalkapal dagang untuk berlabuh di pelabuhannya. Meskipun demikian bukan berarti peran Melayu dalam bidang perdagangan terhenti sama sekali. Pelabuhan Jambi tetap berperan paling tidak sebagai tempat penjualan komoditas yang berasal dari kawasan hulu sungai Batanghari Dan serta untuk membeli barangbarang keperluan masyarakat sekitar daerah aliran sungai tersebut.

Peran Jambi kembali penting pada abad ke-11, tepatnya setelah Sriwijaya mengalami kekalahan dalam perperangannya melawan kerajaan Cola dari India yakni pada tahun 1024 dan 1030, kerajaan Sriwijaya menjadi lemah sehingga dimanfaatkan oleh sebagian daerah bawahan untuk meloloskan diri dari kekuasaan Sriwijaya. Seratus tahun setelahnya, tahun 1230, Grahi dan Tambralingga di semenanjung melepaskan diri dari Sriwijaya.

Melemahnya Sriwijaya juga dimanfaatkan oleh melayu (Jambi). Pada akhir abad ke-12 Kerajaan Melayu bangkit di bawah raja Srimat Trailokyaraja 
Maulibhusana Warmadewa. Catatan Chau-Ju-Kua masih menyebutkan tentang negara-negara bawahan Sriwijaya yang berjumlah 15 buah, tetapi catatan itu telah mencantumkan Melayu sebagai negara bawahan San-totsi (Sriwijaya) (Mulyana, 2011). Dengan demikian di Tenggara pusat Sriwijaya telah berpusat di Jambi atau Kerajaan Melayu telah mengambil alih kedudukan dan kekuasaan Sriwijaya.

Sumber Cina dari Chu Yu's Ping-chou ko-tan menggambarkan peran Jambi dalam perdagangan internasional pada abad ke-11. Lebih jauh dalam sumber itu menyatakan bahwa setiap negara di Laut Selatan mempunyai pemimpinnya sendiri. Sant-fo-tsi (Jambi) selalu digambarkan sebagai sebuah negara besar. Dia mempunyai tulisan sendiri, dan para pedagang menyatakan bahwa penduduk di sana dapat meramalkan gerhana matahari dan bulan di masa yang akan datang, tetapi orang Cina tidak mengerti tulisan tersebut. Negeri tersebut menghasilkan banyak kayu cendana dan kemenyan, dan produk-produk ini adalah barang dagangan dengan Cina (Mc Kinnon, 1992).

San-fo-tsi memonopoli perdagangan kayu cendana. Raja memerintahkan pedagang untuk membeli kepadanya. Dengan demikian harga naik beberapa kali lipat. Pedagang asing tak berani membelinya secara pribadi (tanpa seizin Raja). Ini adalah sistem yang cerdas. Negara ini persis di tengah Laut Selatan. Negaranegara Arab berada jauh di sebelah Baratnya. Orang China bila pergi ke Arab mampir di Sanfotsi, memperbaiki kapal mereka dan bertukar barang. Pedagang dari tempat jauh berkumpul disana. Karenanya, negara ini dianggap sangat makmur.

Dalam kurun abad 11 dan 12 sumber Cina mencatat sejumlah misi upeti dari Melayu ke Istana Kekaisaran China. Pengiriman misi ke Cina pada dasarnya adalah cara untuk memperoleh status yang tinggi yang mata China, selain dirancang untuk meningkatkan perdagangan.

Misi-misi itu berlangsung tahun 1079-1082, 1084, 1088, 1090, 1094, 1156-1178. Pengiriman itu segera setelah Melayu bangkit kembali sebagai penguasa merdeka. Dua misi terakhir adalah misi diplomatik. Misi tahun 1156/1157 membawa upeti terdiri dari ambergris, mutiara, terumbu karang, cula badak, papan kamper, barang pecah belah Arab, berlian, cincin mata kucing cincin mutiara besar, musang, gula Arab, air mawar, pedang baja, kemenyan, gading gajah dan rempahrempah.

Misi 30 tahun kemudian membawa upeti yang jauh lebih bervariasi. Selai tetap membawa jenis barang yang dibawa terdahulu, ada pula kayu cendana, cangkir anggur berlapis emas, toples, bermacam-macam tipe nampan dan perabotan makan minum dan lainnya.

Semua itu mewakili sejumlah besar barang dagangan yang menurut Mc Kinnon dibawa oleh sebuah armada kapal kecil, sebagai imbalannya Kaisar memberikan sejumlah uang yang kira-kira seimbang nilainya dengan upeti tersebut dan Raja memberi gelar pada para pemimpin misi.

Pengiriman misi itu menunjukkan bahwa Melayu tidak hanya menerima kedatangan para pedagang di pelabuhannya, melainkan juga terlibat aktif pergi berdagang ke luar negeri. Saying untuk periode ini belum ditemukan catatan-catatan tentang besaran/volume komoditas yang dibawa oleh para pedagang asing ke pelabuhan Melayu. Namun banyaknya bukti tinggalan arkeologis seperti yang terdapat di Suak Kandis, Muaro Jambi, dan lokasi lainnya di daerah sepanjang aliran Sungai Batanghari menunjukkan ramainya kegiatan perdagangan.

Pada akhir abad 12, telah berkembang secara dramatik. Sumber cina mengatakan bahwa Jambi tidak lagi menjadi Pelabuhan yang penting. Hal itu disebabkan karena Jambi tidak memiliki produk sendiri untuk para pedagang, hanya mengandalkan kekuatan untuk memaksa kapal asing untuk memasuki pelabuhannya. Dengan terbukanya akses ke pedalaman yang kaya, Jambi tidak lagi menarik bagi para pedagang. Terbukanya akses ke pedalaman sangat menguntungkan bagi para pedagang karena terbebas dari campur tangan pihak lain, perantara, serta pembayaran pajak.

Selain itu, disebabkan pula oleh munculkan sumber alternatif yang terbuka untuk perdagangan. Misalnya, munculnya Kota Cina sebagai bandar perdagangan yang terletak di pantai Timur Laut Sumatera. Di sini para pedagang Cina dan India memperoleh prioritas berharga secara langsung dari daerah pedalaman tanpa campur tangan pihak lain, perantara, serta pembayaran pajak.

\section{Perdagangan Merica}

Jambi kembali muncul sebagai bandar perdagangan penting di Nusantara Ketika merica menjadi komoditas perdagangan penting dalam perdagangan internasional pada abad $16-17$. Sejak awal abad 17, permintaan akan merica sangat tinggi. Jambi adalah salah satu penghasil merica yang banyak di antara negeri-negeri yang ada di Nusantara. Dalam tahun 1580an Jambi telah menghasilkan merica sebanyak 40.000 hingga 50.000 kantong lada (Lindayanti, 2013).

Keberadaan Jambi sebagai daerah penghasil merica sudah dikenal jauh sebelum kedatangan bangsa Eropa. Menurut Andaya, merica liar yang belum diolah telah lama menjadi komoditas dalam perdagangan internasional dan sebagai barang ekspor Palembang dan Jambi pada abad ke 8. Untuk bumbu makanan, dan sebagai afrodisial yang dapat merangsang birahi (Andaya, 2016). Selain itu berguna untuk mencegah masuk angin, mencerna daging, membangkitkan selera makan, memperkuat ingatan, menjernihkan suara, memperbaiki pendengaran, menyembuhkan encok dan pegal yang disebabkan oleh cuaca dingin.

Produksi merica meningkat pesat setelah penduduk Bumi Putra (lokal) menyadari tingginya 
permintaan di pasaran penghasil merica di Sumatera adalah Minangkabau. Faktor sifat dan didukung oleh iklim hangat dan cuaca curah hujan yang melebihi 2500 $\mathrm{mm} /$ tahun menyebabkan tanaman merica sangat cocok tumbuh di pedalaman Sumatera.

Seiring dengan kejatuhan Malaka, kedatangan Portugis pada tahun 1511 yang berakibat pada tumbuhnya bandar-bandar perdagangan di Nusantara, para penduduk Minangkabau Selatan secara bertahap mulai memperkenalkan perkebunan merica di daerah rantau seperti yang berada di hulu sungai Batanghari. Menurut Andaya, Sumatra (Jambi) tidak membataskan waktu panjang untuk untuk melampaui India sebagai negara Lintas Samudera, pelaku utama perdagangan merica ini adalah orang-orang Cina, terutama mereka yang berasal dari Fujian (Andaya, 2016)

Pada tahun 1626, Pelabuhan-pelabuhan Provinsi Fujian memberangkatkan 18 Jung yang berlayar ke Asia Tenggara. Rinciannya 4 Jung berlayar ke Batavia, 4 Jung ke Kamboja, 4 Jung ke Kochin Cina, 3 Jung ke Siam, 1 Jung ke Patani dan 1 jung ke Jaratan (Gresik) (Van Leur, 2015). Hingga kedatangan Belanda, Jambi adalah salah satu daerah sumber merica bagi Cina meskipun mereka mengandalkan Banten sebagai pemasok paling penting (Roeloffz, 2016).

Selain Cina, Jambi merupakan pelabuhan merica bagi para pedagang nusantara dari mancanegara seperti Jawa, Siam, Portugal, Inggris, dan Belanda. Dua bangsa yang disebutkan terakhir bahkan berupaya mendirikan kantor dagang mereka di Jambi. Dikatakan oleh Marsden, Inggris mendirikan pos dagang di sebuah pulau kecil dekat muara sungai, sedangkan Belanda mendirikannya agak jauh, ke arah hulu sungai (Marsden, 2016). Guna memperlancar urusan perdagangan, Sultan biasanya mengangkat orang asing Cina Islam sebagai Syahbandar. Jabatan Syahbandar punya kedudukan sebagai perantara antara Istana dan pasar. Posisi jabatan ini sangat strategis dan sempurna untuk kemitraan yang menguntungkan dengan penguasaan di satu pihak dan orang asing yang memerlukan restu di pulau lain. Seorang syahbandar biasanya diangkat dari saudagar asing terkemuka untuk memberi jaminan bahwa protokol diperhatikan dan bea pelabuhan dibayar oleh saudagar asing yang datang melalui laut (Reid, 1999).

Perdagangan merica pada abad 17 berdampak pada kekuatan dari kemakmuran. Jambi muncul sebagai kerajaan yang disegani di Nusantara. Pelabuhan Jambi dikatakan oleh sejarawan sebagai pelabuhan nomor dua paling ramai di Sumatera dan berada di atas Palembang. Jung-jung Cina berdatangan secara teratur ke Jambi pada bulan April dan Mei. Beberapa di antaranya langsung dari Cina, dan beberapa lainnya dari Patani Sebanyak 40 kapal Jawa biasanya datang setiap tahun mengangkut beras dari Jawa (Andaya, 2016). Dari segi politis kekuatan Jambi cukup diperhitungkan. Jambi terlibat aktif dalam konstalasi politik antar kerajaan di Nusantara, dan sering terlibat dalam penyelesaian konflik antar kerajaan. Contohnya pada tahun 1659, VOC pernah meminta Jambi sebagai penengah dalam konflik antara VOC dengan Banten. Keberhasilan Jambi sebagai negosiator sangat dihargai oleh Belanda maupun Banten sehingga meningkatkan kehormatan Jambi diantara kerajaan-kerajaan yang ada di Nusantara (Andaya, 2016).

Efek perdagangan merica juga tampak dalam bidang budaya. Kekayaan Jambi memungkinkan rajanya untuk memelihara dan mempertahankan gaya hidup yang menyamai, bahkan melebih kerabat dan pesaingnya yang juga makmur di Palembang. Kekayaan itu juga telah mendorong raja Jambi untuk menerapkan budaya Jawa dalam lingkungan istananya. Sebuah Maklumat dideklarasikan agar orang pedalaman melepaskan pakaian Melayu dan mengenakan pakaian Jawa jika mereka hendak tampil di Istana. Untuk mempertunjukkan "kejawaan"nya, Raja juga menggelar acara pertunjukan seperti yang lazim digelar di Istana Jawa, misalnya, Pertandingan ksatria berkuda. Pertandingan itu adalah suatu pertunjukkan kemahiran dalam menunggang kuda dan bertempur melawan binatang buas. Acara ini bukanlah hiburan semata, melainkan sebagai ajang untuk memperlihatkan kebolehan peserta di depan raja. Dalam acara tersebut orang-orang yang disenangi oleh raja akan diberi hadiah sedang yang tak disenangi akan dipermalukan (Andaya, 2016).

Sayangnya kemakmuran Jambi tidak bertahan lama. Memasuki akhir abad 17, kerajaan mengalami kemerosotan. Banyak faktor dapat dikaitkan sebagai penyebab. Yang pertama adalah peperangan dengan Johor yang terjadi dalam rentang tahun 1667 dan 1673, dan berujung dengan kekalahan di pihak Jambi. Penyebab perang itu adalah adanya upaya kedua kerajaan untuk memperoleh hegemoni di Selat Malaka. Akan tetapi sebab utama peperangan ini adalah masalah hubungan perkawinan antara Raja Muda Johor putra Sultan Hammad Syah (1613-1623) yang kawin dengan putri Jambi, seorang putri Pangeran Ratu. Intrik muncul ketika Tun Abdul Jamil, Laksamana Johor pada masa pemerintahan Sultan Abdul Jalil Riayat Syah menghalang-halangi putri Jambi yang merupakan istri Raja Muda untuk datang ke Johor. Peristiwa itu dipandang sebagai penghinaan Johor terhadap Jambi, sehingga menimbulkan perang terbuka (Satrono Kartodirdjo, 1999). Pada tahun 1673, angkatan perang Jambi melakukan serangan mendadak atas Johor guna membalas serangan Johor atas Jambi yang dilakukan empat tahun sebelumnya. Dalam serangan atas Johor tersebut Jambi berhasil merampas banyak harta kekayaan Johor serta membawa 3500 orang ke Jambi sebagai tawanan. Sebuah catatan sejarah mengatakan bahwa dalam melakukan serangan itu Jambi menggunakan 64 kapal tetapi ketika pulang Jambi membawa lebih dari 204 kapal. Tetapi pada tahun 1679, Johor yang didukung armada kapal sebanyak 300 buah, 
serta dibantu oleh orang-orang Bugis berhasil mengalahkan Jambi dan memaksa Sultan Jambi untuk membayar rampasan perang (Abdullah Zakaria, 2010).

Kekalahan di atas menyebabkan Jambi kehilangan posisinya sebagai pelabuhan lada utama. Situasinya diperparah dengan terjadi konflik internal antar bangsawan kesultanan yang oleh Andaya digambarkan sebagai konflik Hulu-Hilir. Dua orang putra Sultan Ingalaga terlibat konflik perebutan kekuasaan dan mewakili dua kawasan tersebut. Kawasan Hilir dipimpin oleh Kiai Gede yang oleh Raja Palembang deberi gelar sebagai Pangeran Ratu. Gambaran data sejarah menunjukan Kiai Gede adalah representasi ketidakadilan yang didukung oleh VOC. Di pihak lain, kawasan Hulu didukung oleh saudara Kiai Gede yang merupakan representasi perjuangan melawan ketidakadilan dipimpin oleh Pangeran Pringgabaya. Kerajaan Minangkabau mendukung Pringbaya dan menganugerahi gelar Sri Maharaja Batu Johan Pahlawan Syah. Pringgabaya membangun perkampungan baru di Muara Tebo yang disebut Mangun Jaya dan memerintah disana, sebagai penguasa kerajaan independen (Andaya, 2016). Konflik itu diperparah oleh prilaku hedonis dan sewenangwenang 3 orang Ratu yang merupakan istri Sultan Ingalaga. Ketiga perempuan kerajaan itu berasal dari luar Jambi (Bugis) menampilkan dirinya bukan sebagai ibu yang peduli, melainkan sebagai manipulator kekuasaan.

Persengketaan hulu-hilir ini sangat memperlemah keberadaan kerajaan dalam berbagai aspek terutama dalam bidang ekonomi. Dengan adanya Pringbaya yang memerintah secara independent, berti hilangnya kontrol hilir atas hulu. Itu artinya hilir kehilangan hampir semua sumber pemasukan raja yang hamper seluruhnya berasal dari hulu.. Orang-orang Minangkabau sebagai produsen utama merica dan emas tidak lagi membawa emas ke Jambi, melainkan ke Indragiri, ke Pantai Barat, ke Palembang, atau ke Tungkal melalui sungai, dimana di sana orang-orang Johor banyak berperan.

Guna memenuhi pemasukannya, Raja bergantung pada hasil pembagian harta rampasan yang dilakukan oleh orang laut yanaag merupakan kaulanya. Orangorang Cina juga menjadi korban dari kemiskinan Raja, karena harta dan barang-barang berharga milik mereka disita untuk membantu meringankan beban Sultan. Hal ini menyebabkan terjadinya eksodus orang-orang Cina dari Jambi ke Palembang. Pada Tahun 1700, sebagian besar pedagang Cina telah pergi dari Jambi dan kawasan Pecinan yang disematkan pada perkampungan sekitar loji Belanda kini hanya tinggal nama karena tak satupun orang Cina yang tinggal di sana,

Ketergantungan Raja akan hasil rampasan yang dilakukan orang laut menyebabkan perompakan di sekitar perairan Jambi semakin marak dan menyebabkan mundurnya perdagangan maritim. Dipadukan dengan eksodus orang-orang Cina terutama ke Palembang menjadikan ibukota kerajaan sama sekali tidak menarik.
Adapun sebab utama dari kemerosotan Jambi adalah turunnya harga merica, sehingga komoditas ini tidak dapat lagi diandalkan sebagai sumber utama pemasukan kerajaan. Kendati daerah Jambi mempunyai produk lain yang dapat diperdagangkan seperti emas dan hasil hutan, tetapi itu tak bisa diharapkan karena orangorang Minangkabau sebagai produsen emas di daerah hulu memperdagangkannya ke Pantai Barat atau ke tempat-tempat lain yang menjanjikan keuntungan lebih. Kembali ke masalah merica, monopoli VOC atas perdagangan merica menyebabkan harganya tidak pernah tinggi seperti masa sebelum Jambi melakukan perjanjian kerjasama dengan VOC. Efek buruk dari perjanjian ini adalah kesewenang-wenangan Belanda atas Jambi dengan mengusir pedagang lain seperti China dan Siam untuk berdagang di Jambi. Belanda selalu menghalangi kapal-kapal Cina dan Siam untuk memasuki pelabuhan Jambi dengan maksud mengendalikan harga merica supaya tetap rendah, serta untuk meramaikan Batavia dalam upaya Belanda menjadikannya pelabuhan terpenting di Nusantara. Yang paling parah adalah bentuk campur tangan Belanda atas urusan internal kerajaan termasuk menentukan pejabatpejabat kerajaan bahkan raja yang akan memerintah. Pada tahun 1687, terjadi konflik antara Sultan Ingalaga yang memerintah dengan putra tertuanya Pangeran Dipati. VOC memihak Pangeran Dipati dan melantiknya sebagai raja dengan memberi namanya Kiai Gede. Bantuan yang diberikan tersebut terpaksa harus dibayar oleh Jambi dengan memberi Belanda peran yang lebih besar terhadap urusan kerajaan. Seiring dengan itu pejabat yang dilantik tentu saja orang-orang yang dimulai sejalan dengan kepentingan Belanda sebaliknya berlawanan dengan upaya memperkuat kerajaan dan kepentingan rakyat.

Dalam kondisi demikian kemunduran Jambi berjalan semakin cepat. Pada abad 18 Jambi tidak dapat lagi dikatakan sebagai bandar perdagangan internasional. Para pedagang asing tidak banyak lagi yang melakukan perdagangan di Jambi, alasannya sebagian disebabkan oleh halangan Belanda, sebagian lain dikarenakan perdagangan di Jambi tidak lagi memberikan keuntungan yang memadai. Pada tahun 1680, ada lima kapal yang datang dari Johor membawa kain India senilai 5000 real. Tetapi mereka hanya dapat menjual begitu sedikit. Pada kesempatan lain seorang India membawa 4000 potong kain, tetapi kain-kain itu harus digudangkan karena minimnya pembeli (Andaya, 2016). Pada tahun 1679, Inggris telah menutup kantor dagangnya di Jambi. Walaupun punya pengaruh politis yang kuat yang dapat menentukan kerajaan sesuai dengan keimanannya akhirnya menutup kantor dagangnya 1768. Pada awal abad 19 para pedagang maritim Nusantara, seperti orang-orang Jawa, Makasar, Cina, dan Eropa tidak lagi berlabuh di Jambi. Pada masa ini Jambi digambarkan orang Eropa sebagai daerah 
miskin dengan pangerannya yang miskin (Scholten, 2008).

\section{SIMPULAN}

Wilayah Jambi terletak pada jalur pelayaran perdagangan antar bangsa yang mulai berkembang sejak permulaan abad Masehi. Jalur itu membentang mulai dari China di belahan Timur, menyusuri kawasan Indocina, Semenanjung Malaya, Selat Malaka, Samudera Hindia terus ke Teluk Persia, atau ke Laut Merah dan berujung di Laut Tengah. Keberadaan jalur itu telah mendorong munculnya berbagai kerajaan di sepanjang jalur tersebut, dan terlibat aktif dalam jaringan pelayaran niaga.

Terutama dalam konteks Jambi keterlibatan itu mengalami pasang surut. Hingga abad 7 terdapat tiga kerajaan yang terlibat aktif, yaitu Koying dan Tupo pada abad 3 dan Kantoli pada abad ke-5. Sumber-sumber China mengabarkan bahwa pada abad ke-6 Kantoli tercatat 3 kali mengirim utusan ke China.

Eksistensi Kantoli diteruskan oleh kerajaan Melayu yang juga diketahui mengirim utusan ke China pada abad ke-7. Tetapi Jambi mengalami kemunduran peranan dalam perdagangan antar bangsa, karena kerajaan Melayu ditaklukan dan dijadikan sebagai bagian kerajaan Sriwijaya yang berpusat di Palembang.

Jambi tampil lagi ke permukaan ketika kerajaan Melayu menggantikan peran Sriwijaya, setelah kerajaan tersebut menderita kekalahan dalam peperangannya dengan kerajaan Cola dari India pada abad 11. Sumber China yang berasal dari Chu-Yu's Ping-Chou Ko-Tan menggambarkan bahwa San-fo-tsi (Jambi) adalah negara besar yang makmur, memiliki ilmu pengetahuan dan kaya dengan hasil bumi. Namun, berita-berita Cina juga menggambarkan kemunduran Jambi pada abad-12. Menurut sumber tersebut kemunduran itu disebabkan karena Jambi tidak memiliki produk sendiri untuk diperdagangkan. Sebab lainnya menurut sumber tesebut adalah munculnya bandar dagang yang terletak di pesisir timur-laut pulau Sumateray, yang mana di tempat tersebut para pedagang India dan China dapat datang langsung ke pedalaman tempat produk perdagangan itu dihasilkan.

Lima abad berselang, Jambi kembali muncul sebagai bandar dagang yang kuat dan berpengaruh. Kebesaran Jambi pada abad 17 berada pada posisi kedua setelah Aceh dan di atas Palembang. Kebesaran ini tercermin daru banyaknya ekspor merica yang melibatkan pedagang asing, serta kuatnya pengaruh Jambi dalam konstalasi politik antar kerajaan di Nusantara, serta gaya hidup yang diterapkan dalam kehidupan istana.

Namun, kejayaan itu menurun secara drastis sejak akhir abad 17. Kemunduran itu disebabkan oleh kekalahan Jambi dalam peperangan dengan kerajaan Johor, dan disusul oleh konflik internal yang melibatkan daerah hilir sebagai ibukota dan pelabuhan, dengan daerah hulu sebagai daerah produsen komoditas perdagangan. Konflik itu menyebabkan sering tersendatnya aliran barang ke pelabuhan Jambi karena dikirim ke pelabuhan lain.

Merosotnya harga merica yang merupakan komoditas peragangan utama, ditambah dengan monopoli dan campur tangan Belanda dalam urusan internal kerajaan, menyebabkan kemerosotan Jambi berlangsung lebih cepat. Pada abad 18, Inggris dan Belanda telah menutup kantor dagangnya di Jambi karena perolehan keuntungan dagang sangat kecil. Memasuki abad 19, seluruh pedagang maritime Nusantara tidak ada lagi yang berlabuh di Jambi.

Alinea-alinea di atas menggambarkan bahwa pasang-surut peran Jambi dalam perdagangan antar bangsa rupanya dipengaruhi oleh sejumlah factor. Pertama, adalah ragam komoditas perdagangan yang dihasilkan serta harga dari komoditas tersebut.Selanjutnya yang lebih penting adalah kemampuan raja dalam menjaga soliditas kekuasannya dan menempatkannya pada posisi yang menguntungkan dalam konteks hubungannya dengan kekuatan lain sebagai pesaing. Terakhir, lemahnya Jambi dalam berhadapan dengan Johor serta ketidakberdayaannya menentang monopoli dan campur tangan Belanda telah menyebabkan kemunduran Jambi berjalan semakin cepat.

\section{DAFTAR PUSTAKA}

A. B. Lapian. Sejarah Indonesia Penilaian Kembali Karya Utama Sejarawan Asing. Depok. Pusat Penelitian Kemasyarakatan dan Budaya. LPUI. 1997.

A.B Lapian."Jambi Dalam Jaringan Pelayaran dan Perdagangan Masa Modern Awal"Makalah disampaikan pada Seminar Sejarah Melayu Kuno.Jambi.1992.

Abdullah Zakaria bin Gazali. "Hubungan Jambi - Johor Abad ke 17. Makalah. Yayasan Warisan Johor Malaysia. 2010

Andaya, Barbara Watson. Hidup Bersaudara Sumatera Tenggara Pada Abad 17 dan 18. Jogyakarta. Penerbit Ombak. 2016.

Burger, DH. Sejarah Ekonomis Sosiologis Indonesia. Jakarta. Pradnya Paramita. 1962

Coedes, George. 2010. Asia Tenggara Masa HinduBuddha. Jakarta: KPG, EFEO, Puslit Arkenas, Forum Jakarta-Paris.

Gusti Asnan, Sungai dan Sejarah Sumatera. Jogyakarta. Penerbit Ombak. 2016.

Hall. D.G.E. Sejarah Asia Tenggara. Surabaya. Usaha Nasional. 1988.

Reid, Anthoni. Dari Ekspansi Hingga Krisis Jaringan Perdagangan Global Asia Tenggara. Jakarta. Yayasan Obor Indonesia. 1999.

Idntimes.com. Diakses tanggal 14 Juli 2021. 
Lindayanti, Dkk. Jambi Dalam Sejarah. Jambi. Disbudpar Prov.Jambi. 2013

Kompas.com 15/01/2020 diakses 26 Juli 2021

Marsden, William,F.R.S. Sejarah Sumatera.Jogyakarta. Penerbit Indo Literasi. 2016

McKinnon, Edwards E. "Malayu Jambi Interlocal and International Trade 1 th to $13^{\text {th }}$ Centuries"Makalah disampaikan pada Seminar Sejarah Melayu Kuno. Jambi.1992

Marwati Djoened Poesponegoro \& Nugroho Notosusanto Sejarah Nasional Indonesia Jilid II. Jakarta. PN Balai Pustaka. 1992

Republika.co.id 14 Februari 2017, diakses tanggal 14 juli 2021

Roeloffz, Meilink M.A.P, Perdagangan Asia dan Pengaruh Eropa di Nusantara Antara 1500 dan Sekitar 1630. Jogyakarta. Penerbit Ombak. 2016

R.Z Leirissa. Sejarah Perekonomian Indonesia. Jakarta. Depdikbud.1996

R.Z Leirissa. "Ternate Dalam Jalur Sutera" Makalah disampaikan pada Seminar Membangun Kembali Peradaban Bahari. Jurusan Sejarah Fakultas Sastra Universitas Indonesia. Depok. 1997.

Sartono Kartodirdjo, Pengantar Sejarah Indonesia Baru: 1500 - 1900. Jakarta. Gramedia.1999

Sartono, S.'Kerajaan Melayu Kuno Pra Sriwijaya di Sumatera"Makalah disampaikan pada Seminar Sejarah Melayu Kuno.Jambi. 1992

Scholten, Elsbet Locher. Kesultanan Sumatera dan Negara Kolonial. Jakarta. Bana KITLV. 2008.

Slamet Mulyana, Sriwijaya. Jogyakarta. LKIS. 2011

Van Leur JC. Perdagangan dan Masyarakat Indonesia Esai-esai Tentang Sejarah Sosial dan Ekonomi Asia. Jogyakarta. Penerbit Ombak. 2015 